\title{
Papanicolaou tests and molecular analyses using new fluid-based specimen collection technology in 3000 Japanese women
}

\author{
N Masumoto', T Fujii",', M Ishikawa', M Mukai', M Saito', T Iwata', T Fukuchi', K Kubushiro', \\ K Tsukazaki' and S Nozawa'
}

'Department of Obstetrics and Gynecology, Keio University School of Medicine, 35 Shinanomachi, Shinjuku-ku, Tokyo I 60-8582, Japan; ${ }^{2}$ Department of Pathology, Keio University School of Medicine, 35 Shinanomachi, Shinjuku-ku, Tokyo I60-8582, Japan

\begin{abstract}
A fluid-based Papanicolaou test has been established to improve sample collection and preparation. This study was the first largescale investigation in Japan to examine the feasibility of using fluid-based Papanicolaou specimens to detect human papillomavirus (HPV) using Hybrid Capture II and polymerase chain reaction (PCR). Three thousand patients who visited Keio University Hospital between October 2000 and February 200I were enrolled in the study. The results of the fluid-based Papanicolaou tests corresponded well with those of conventional Papanicolaou smears (96.8\% concordance). The sensitivities of cervical neoplasia detection using the fluid-based Papanicolaou test (73.9\%) and Hybrid Capture II (76.3\%, $P=0.55)$ were not significantly different. Among the cervical intraepithelial neoplasia 3 and squamous cell carcinoma specimens, HPV 16 and HPV 52 were predominantly detected using the PCR method. Although some DNA samples extracted from the fluid-based specimens were degradaded, PCR and direct sequencing could be performed without difficulty even after I year of specimen storage. We conclude that fluid-based Papanicolaou specimens can be applied to investigate HPV infection.

British Journal of Cancer (2003) 88, I883-1888. doi:I0.1038/sj.bjc.660I023 www.bjcancer.com

(c) 2003 Cancer Research UK
\end{abstract}

Keywords: fluid-based specimen; cytological techniques; Hybrid Capture II; human papillomavirus; polymerase chain reaction

The fluid-based Papanicolaou specimen collection method is widely used for primary cervical cancer screening (Awen et al, 1994; Roberts et al, 1997; Bolick and Hellman, 1998), largely because of the improvement in specimen quality, the advantage of increased sensitivity, and a reduction in the false negative rate for squamous intraepithelial lesions (Linder and Zahniser, 1997; Park et al, 2001), compared to the conventional Papanicolaou smear method. Fluid-based specimens can be stored at ambient temperature for a longer period; therefore, this collection system offers the advantage that once the specimen has been collected, there is no need to collect additional specimens from the patient to perform a second Papanicolaou test or conduct further investigations. Studies evaluating the clinical utility of Hybrid Capture II (HC II) human papillomavirus (HPV)-DNA testing have also been performed (Clavel et al, 1998; Lin CT et al, 2000a; Yamazaki et al, 2001; Castle et al, 2002). Genital HPV has been reported to be related to cervical cancer carcinogenesis and some types of HPV; HPV 16, for example, is associated with a high risk of cervical neoplasia (Josefsson et al, 2000; Woodman et al, 2001). HC II is a HPV detection test designed to detect 18 types of HPV using microtitre plates and is an appropriate method for HPV screening. We performed the HC II test using fluid-based specimens from patients in whom biopsy studies were also performed to determine whether this method is appropriate for detecting cervical neoplasia in Japan. We also performed HPV typing using fluid-based specimens. We previously reported an HPV-DNA transcript

*Correspondence: Dr T Fujii; E-mail: fujiit@sc.itc.keio.ac.jp Received 19 November 2002; revised 20 March 2003; accepted 25 March 2003 detection method using cytologic specimens and reverse transcriptase-nested polymerase chain reactions (PCR) (Fujii et al, 1995), and a method for detecting multiplex HPV infection using PCR single-stranded DNA-conformational polymorphism analysis (Nakagawa et al, 2002). We applied these methods to the fluidbased specimens and then performed direct sequencing of the PCR products.

HPV testing with PCR using fluid-based specimens, in conjunction with cytologic and biopsy follow-up, has been reported to be useful for estimating the significance of atypical squamous cells of undetermined significance (Crum et al, 1999), and the concordance rate of HC II and PCR has been reported to be approximately $90 \%$ for fluid-based specimens (Peyton et al, 1998). HPV screening with HC II and HPV-typing analysis can be performed using residual specimens without the need to collect a second specimen from the patient; this collection system is thus of great advantage to both patients and clinicians. To our knowledge, however, the feasibility of using the fluidbased Papanicolaou test in conjunction with HPV testing has not been examined in Japan. Japan has more than 5000 cytotechnologists, and cytology has been established as an independent method of screening for cervical neoplasia. This study is the first large-scale investigation in Japan to examine the utility of fluid-based Papanicolaou specimens. In addition, the storage conditions for fluid-based specimens are controversial, and some of the genomic DNA was degraded in the samples that we examined. Therefore, we also investigated the quality of the genomic DNA in the specimens. This study was undertaken to evaluate the feasibility of using fluid-based Papanicolaou specimens to detect HPV using both the HC II and PCR methods in Japan. 


\section{MATERIALS AND METHODS}

\section{Sample preparation}

Three thousand patients who visited our clinic between October 2000 and February 2001 were enrolled in the study. The patient population consisted of a mixture of asymptomatic women and those who were being followed-up for previous atypical smears or the treatment of previous genital malignancies. Cervical samples were collected using both the conventional method and the ThinPrep method, simultaneously. The conventional smears were collected with a survexbrush and fixed in ethanol at the time of collection. The ThinPrep samples were collected using the ThinPrep Cytology Collection System (Cytyc Corporation, Boxborough, USA), according to the manufacturer's directions. Out of the 3000 cases, colposcopy and biopsy studies were performed in 557 patients. The ThinPrep sample vials were stored at ambient temperature and used for the HPV-DNA analysis within 12 months of collection. Specimens from 477 random patients in whom biopsy studies had also been performed were subjected to HPVDNA detection using HC II (Digene Inc., Silver Spring, USA), while specimens from 146 random cases diagnosed as having cervical neoplasia on the basis of biopsy studies were subjected to HPVDNA detection using PCR. The HC II and PCR test results were compared in 133 cases. HPV typing and sequencing analysis were performed in all the PCR-positive cases. Informed consent was obtained from each biopsy study participant after an oral explanation of the study.

\section{Fluid-based cervical cytology}

Thin-layer slides were prepared using the ThinPrep 2000 Automated Slide Processor (Cytyc Corp., Boxborough, USA), according to the manufacturer's instructions. Briefly, the vial containing the cells was placed in the processor, and a dispersion cycle homogenised the cell suspension. The cells were then automatically collected on a polycarbonate filter membrane. A thin, evenly dispersed monolayer of cells was deposited from the filter onto the slide in a circle with a diameter of $20 \mathrm{~mm}$. Extraneous mucus and blood were removed in the process. The slides were then manually removed from the processor and stained using the Papanicolaou method. All slides, both conventional and ThinPrep, were screened by three cytotechnologists (MS, HT, and YN). The diagnostic adequacy of the fluid-based Papanicolaou specimens was compared with those of both conventional Papanicolaou smear and biopsy specimens.

\section{HPV detection using HC II}

HPV-DNA detection was performed using the commercially available HC II hybrid capture technique. Fluid-based specimens were analysed for the presence of low-risk HPV types 6, 11, 42, 43, and 44 using a Probe A cocktail, and for high-risk HPV types 16, $18,31,33,35,39,45,51,52,56,58,59$, and 68 using a Probe B cocktail. The sensitivity of the HC II method for detecting cervical neoplasia was then compared with that of the ThinPrep slides. The enzyme-linked immunosorbent assay was based on a sandwich hybridisation followed by a nonradioactive alkaline phosphatase reaction with chemiluminescence on microplates.

\section{DNA extraction}

Approximately $10 \mathrm{ml}$ of preserved fluid was centrifuged at 3000 r.p.m. for $30 \mathrm{~min}$. The pellet was washed once in phosphatebuffered saline, followed by genomic DNA extraction using proteinase $\mathrm{K}$ and phenol-chloroform treatment. The quality and quantity of the extracted genomic DNA were monitored using ethidium bromide-stained agarose gel electrophoresis.

\section{Polymerase chain reaction}

The presence of intracellular HPV DNA was determined using PCR analysis with consensus primer pairs (L1C1, L1C2) (Yoshikawa et al, 1991), designed to amplify an approximately 250-bp segment of DNA. These consensus primer pairs target the HPV L1 open reading frame and detect a broad range of genital HPVs. A $50 \mu \mathrm{l}$ volume containing $20 \mathrm{~mm}$ Tris $\mathrm{HCl}$ buffer ( $\mathrm{pH} 8.0$ ), $50 \mathrm{~mm} \mathrm{KCl}$, $0.2 \mathrm{~mm}$ dNTP mix, $2 \mathrm{~mm} \mathrm{MgCl} 2,0.5 \mu \mathrm{M}$ of each forward and reverse primer, and $0.25 \mathrm{U}$ of Taq polymerase (TaKaRa, Otsu, Japan) was used for each reaction. After an initial period of denaturation at $95^{\circ} \mathrm{C}$ for $10 \mathrm{~min}, 43$ cycles of reactions were performed, each consisting of denaturation at $95^{\circ} \mathrm{C}$ for $1.5 \mathrm{~min}$, annealing at $48^{\circ} \mathrm{C}$ for $1.5 \mathrm{~min}$, and extension at $70^{\circ} \mathrm{C}$ for $2 \mathrm{~min}$. PK114/K, a variant HPV16 clone provided by Dr Mattias Durst, was used as a positive control.

\section{Direct sequencing of PCR products}

A partial L1 sequence was amplified by the primer L1C1. The amplified PCR products were purified, and automated sequencing was performed using an ABI Prism 3100 Genetic Analyser (Applied Biosystems, Foster City, CA, USA). The HPV type was determined based on an approximately 200 bases of L1 sequence and a search of the NCBI database (GenBank sequences; http://www.ncbi.nlm. nih.gov/blast/Blast.cgi) using Sequencing Analysis 3.3 software (The Perkin-Elmer Corporation, Norwalk, CT, USA).

\section{Statistics}

Correlations in sensitivity between the ThinPrep slide and conventional Papanicolaou smear tests for the detection of cervical neoplasia and the concordance rate of each cytological method with the histological results were examined using McNemar's $\chi^{2}$ test. Correlations in sensitivity between the ThinPrep slide and HC II tests for the detection of cervical neoplasia were examined using the $\chi^{2}$ test. Correlations in the concordance rate of the HC II and PCR test results between the cases with CIN1 and those with CIN2, CIN3, and SCC were examined using Fisher's exact probability test. The HPV-positive rates were also examined using Fisher's exact probability test. $P$-values of 0.05 or less were considered to be statistically significant.

\section{RESULTS}

Cytologic studies were performed in all 3000 cases. Twelve cases of glandular dysplasia, 11 cases of adenocarcinoma, five cases of adenocarcinoma in situ and one case of small cell carcinoma, all diagnosed cytologically, were excluded; the diagnostic results of the ThinPrep slide and conventional Papanicolaou smear specimens were then compared in the remaining 2971 cases (Table 1).

Table I Diagnosis of ThinPrep slides and conventional smears

\begin{tabular}{lrrrrrr}
\hline & \multicolumn{6}{c}{ Conventional } \\
\cline { 2 - 7 } ThinPrep & Neg & BA & LGSIL & HGSIL & SCC & Total \\
\hline Neg & 2579 & 9 & 18 & 0 & 0 & 2606 \\
BA & 3 & 16 & 4 & 2 & 0 & 25 \\
LGSIL & 17 & 3 & 151 & 21 & 0 & 192 \\
HGSIL & 2 & 0 & 12 & 106 & 4 & 124 \\
SCC & 0 & 0 & 0 & 0 & 24 & 24 \\
Total & 2601 & 28 & 185 & 129 & 28 & $297 \mid$ \\
\hline
\end{tabular}

$\mathrm{Neg}=$ negative slide or smear; $\mathrm{BA}=$ benign atypia; $\mathrm{LGSIL}=$ low-grade squamous intraepithelial lesion; HGSIL = high-grade squamous intraepithelial lesion; $\mathrm{SCC}=$ squamous cell carcinoma. 
These 2971 cases consisted of patients with negative findings, benign atypia, low-grade squamous intraepithelial lesions, highgrade squamous intraepithelial lesions (HGSIL), or squamous cell carcinoma (SCC), based on their Papanicolaou test results. The concordance rate between the fluid-based Papanicolaou test results and the conventional Papanicolaou smear results was high $(96.8 \%$, 2876 out of 2971 cases). The percentage of cases with benign atypia did not differ significantly between the ThinPrep slide results $(0.8 \%, 25$ out of 2971 cases) and the conventional Papanicolaou smear results $(0.9 \%, 28$ out of 2971 cases, $P=0.66)$.

Biopsy studies were performed in 557 of the 3000 cases. Based on the histological diagnosis, five cases of adenocarcinoma, five cases of adenocarcinoma in situ, three cases of condyloma acuminatum, two cases of adenosquamous cell carcinoma, and one case of small cell carcinoma were excluded from the 557 cases. A comparison between the cytological and histological results for the remaining 541 cases is shown in Tables 2 and 3. The absolute concordance rate between the cytological and histological results was $73.9 \%$ ( 400 out of 541 cases) for the fluid-based Papanicolaou test and $73.2 \%$ (396 of 541 cases) for the conventional Papanicolaou smear. This difference was not significant $(P=0.12)$. The detection sensitivities for cervical intraepithelial neoplasia1 (CIN1), CIN2, CIN3, and SCC were 53.2, 81.5, 94.3, and $100.0 \%$, respectively, for the ThinPrep slides, and 55.3, 83.3, 96.2, and $100.0 \%$, respectively, for the conventional Papanicolaou smear specimens. These differences were not significant for any histological category $(P>0.4)$. In the same manner, the CIN and SCC detection sensitivities also did not differ between the ThinPrep slides $(73.9 \%, 161$ out of 218 cases) and the conventional

Table 2 Comparison between histological and conventional cytological diagnosis

\begin{tabular}{lrrcccc}
\hline & \multicolumn{6}{c}{ Histological diagnosis } \\
\cline { 2 - 7 } Conventional & CC & CINI & CIN2 & CIN3 & SCC & Total \\
\hline Neg & 262 & 40 & 7 & 0 & 0 & 309 \\
BA & 8 & 2 & 2 & 1 & 0 & 13 \\
LGSIL & 41 & 40 & 14 & 2 & 0 & 97 \\
HGSIL & 12 & 12 & 31 & 43 & 1 & 99 \\
SCC & 0 & 0 & 0 & 6 & 16 & 22 \\
Total & 323 & 94 & 54 & 53 & 17 & 541
\end{tabular}

Neg = negative slide or smear; $B A=$ benign atypia; $L G S I L=$ low-grade squamous intraepithelial lesion; HGSIL=high-grade squamous intraepithelial lesion; $C C=$ chronic cervicitis; $\mathrm{CIN}=$ cervical intraepithelial neoplasia; $\mathrm{SCC}=$ squamous cell carcinoma.
Papanicolaou smear specimens $(75.7 \%, 165$ out of 218 cases, $P=0.22$ ).

An HC II analysis was randomly performed in 477 of the 541 cases who underwent biopsy studies. Only cases positive for highrisk HPV were regarded as positive in this study; cases positive for only low-risk HPV were regarded as negative. The sensitivity of HC II for detecting CIN1, CIN2, CIN3, and SCC was $59.1 \%$ (55 out of 93 cases), $84.9 \%$ ( 45 out of 53 cases), $90.6 \%$ (48 out of 53 cases), and $100.0 \%$ (16 out of 16 cases), respectively. The overall CIN and SCC detection sensitivities did not differ significantly between the HC II (76.3\%, 164 out of 215 cases) and the ThinPrep slide $(73.9 \%$, 161 out of 218 cases, $P=0.56$ ) test results.

Table 4 summarises the HPV-positive rates as detected using direct sequencing of the PCR products. Fisher's exact probability test revealed that the frequency of cases with CIN3 or SCC, compared to those with CIN1 or CIN2, in the HPV 16-positive cases $(67.6 \%, 25$ out of 37 cases) or HPV 52-positive cases $(62.5 \%$, 10 out of 16 cases) was significantly higher than that of the other HPV types $(19.4 \%, 12$ out of 62 cases, $P<0.00001$ for HPV 16, $P$ $<0.01$ for HPV 52). We also found that the frequency of cases with adenocarcionoma or adenocarcinoma in situ, compared to those with CIN or SCC, in the HPV 18-positive cases $(30.8 \%$, four out of 13 cases) was higher than that of the other HPV types $(0.9 \%$, one out of 107 cases, $P<0.001)$. HPV 18 was also detected in one case of the adenosquamous cell carcinoma.

The concordance rate between the HC II and PCR test results was $68.1 \%$ (32 out of 47 cases) in cases with CIN1, 88.4\% (76 out of 86 cases) in cases with CIN2, CIN3, or SCC, and $81.2 \%$ (108 out of 133 cases) overall (Table 5). The concordance rate between test

Table 3 Comparison between histological and ThinPrep cytological diagnosis

\begin{tabular}{lrrrcrc}
\hline & \multicolumn{6}{c}{ Histological diagnosis } \\
\cline { 2 - 7 } ThinPrep & CC & CINI & CIN2 & CIN3 & SCC & Total \\
\hline Neg & 264 & 42 & 7 & 2 & 0 & 315 \\
BA & 6 & 2 & 3 & 1 & 0 & 12 \\
LGSIL & 41 & 40 & 15 & 3 & 0 & 99 \\
HGSIL & 12 & 10 & 29 & 43 & 3 & 97 \\
SCC & 0 & 0 & 0 & 4 & 14 & 18 \\
Total & 323 & 94 & 54 & 53 & 17 & 541 \\
\hline
\end{tabular}

Neg = negative slide or smear; $B A=$ benign atypia; $L G S I L=$ low-grade squamous intraepithelial lesion; HGSIL = high-grade squamous intraepithelial lesion; $\mathrm{CC}=$ chronic cervicitis; $\mathrm{CIN}=$ cervical intraepithelial neoplasia; $\mathrm{SCC}=$ squamous cell carcinoma.

Table 4 Positive rate of HPV by PCR

\begin{tabular}{|c|c|c|c|c|c|c|}
\hline \multirow[b]{2}{*}{ Histological diaganosis } & \multirow[b]{2}{*}{ Overall } & \multicolumn{5}{|c|}{ Infection of HPV-(type of HPV) } \\
\hline & & HPV 16 & HPV 52 & Others & HPV 18 & Others \\
\hline CINI & $37 / 51$ (72.5\%) & $4(7.8 \%)$ & $2(3.9 \%)$ & $31(60.8 \%)$ & I (2.0\%) & 36 (70.6\%) \\
\hline CIN2 & $31 / 33(93.9 \%)$ & 8 (24.2\%) & $4(12.1 \%)$ & $19(57.6 \%)$ & $5(15.2 \%)$ & 26 (78.8\%) \\
\hline CIN3 & $35 / 4 \mid(85.4 \%)$ & $19(46.3 \%)$ & $9(22.0 \%)$ & $7(17.1 \%)$ & I (2.4\%) & $34(82.9 \%)$ \\
\hline SCC & $12 / 14(85.7 \%)$ & $6(42.9 \%)$ & ( $(7.1 \%)$ & $5(35.7 \%)$ & $2(14.3 \%)$ & $10(71.4 \%)$ \\
\hline AIS & $2 / 3(66.7 \%)$ & $0(0 \%)$ & $0(0 \%)$ & 2 (66.7\%) & I (33.3\%) & I (33.3\%) \\
\hline$A C$ & $3 / 3(100 \%)$ & $0(0 \%)$ & $0(0 \%)$ & $3(100 \%)$ & $3(100 \%)$ & $0(0 \%)$ \\
\hline \multirow[t]{2}{*}{ ASC } & $1 / 1(100 \%)$ & $0(0 \%)$ & $0(0 \%)$ & I (100\%) & I (100\%) & $0(0 \%)$ \\
\hline & & $* P<0.0000$ I & $* * P<0.01$ & & ***** $P<0.00$ । & \\
\hline
\end{tabular}

$\mathrm{CIN}=$ cervical intraepithelial $\quad$ neoplasia; $\quad \mathrm{SCC}=$ squamous cell carcinoma; $\mathrm{AIS}=$ adenocarcinoma in situ $\mathrm{AC}=$ adenocarcinoma; $\mathrm{ASC}=$ adenosquamous cell carcinoma. *Fisher's exact probability test for positivity of HPV 16 vs others between CINI-CIN2 and CIN3-SCC. **Fisher's exact probability test for positivity of HPV 52 vs others between CINI-CIN2 and CIN3-SCC. ****Fisher's exact probability test for positivity of HPV I 8 vs others between CINI-SCC and AIS-AC. 
Table 5 Comparison between HC II and PCR for the detection of highrisk HPV DNA

\begin{tabular}{|c|c|c|c|c|}
\hline & \multirow{2}{*}{\multicolumn{2}{|c|}{$\begin{array}{l}\text { CINI } \\
\text { HC II }\end{array}$}} & \multicolumn{2}{|c|}{ CIN2, CIN3, and SCC } \\
\hline & & & \multicolumn{2}{|c|}{ HC II } \\
\hline & $(+)$ & $(-)$ & $(+)$ & $(-)$ \\
\hline $\mathrm{PCR}(+)$ & 20 & 13 & 72 & 4 \\
\hline$(-)$ & 2 & 12 & 6 & 4 \\
\hline
\end{tabular}

$\mathrm{CIN}=$ cervical intraepithelial neoplasia; $\mathrm{SCC}=$ squamous cell carcinoma.

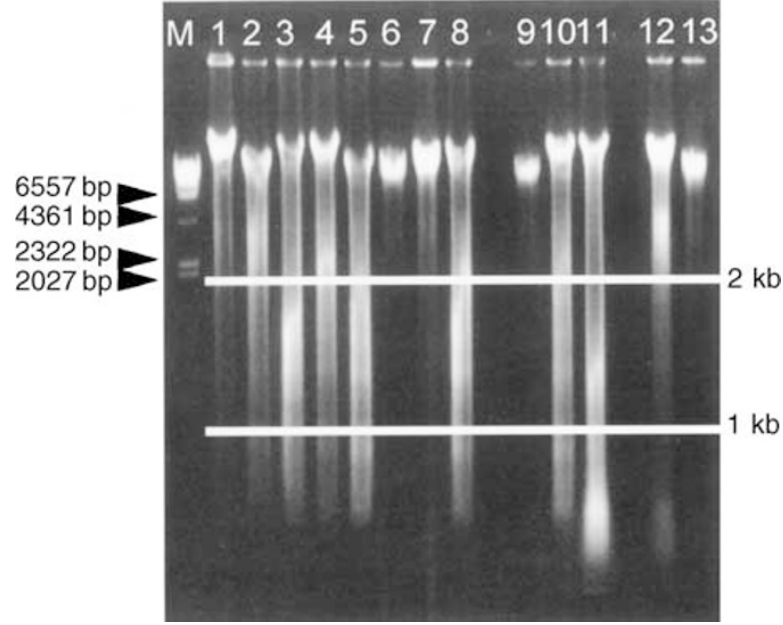

Figure I Estimating the quality of the extracted genomic DNA. Genomic DNA was electrophoresed on a $0.8 \%$ agarose gel. The quality of the extracted genomic DNA was classified into three categories. Genomic DNA samples 1, 2, 4, 6, 7, 9, 12, and 13 were classified as exhibiting grade I degradation. Genomic DNA samples 3, 5, 8, and 10 were classified as exhibiting grade 2 degradation. Genomic DNA sample I I was classified as exhibiting grade 3 degradation. M shows the $\lambda$ DNA/HindllI marker.

results for cases with CIN2, CIN3, and SCC was higher than that for cases with CIN1 $(P<0.01)$.

While performing the PCR analyses, we found that some DNA samples extracted from the fluid-based specimens were degradaded when examined by electrophoresis. We analysed 170 samples in which the yield of the extracted DNA was more than $5 \mu \mathrm{g}$ in total. We then categorised the extracted DNA samples into grade 1 , grade 2 , or grade 3 degradation (Figure 1). DNA samples containing fragments mainly larger than $2 \mathrm{~kb}$ were classified as grade 1 degradation. DNA samples containing $1-2 \mathrm{~kb}$ fragments were classified as grade 2 degradation. DNA samples containing fragments smaller than $1 \mathrm{~kb}$ were classified as grade 3 degradation. Grade 1, grade 2, and grade 3 degradation were seen in 96 cases (56\%), 51 cases (30\%), and 23 cases (14\%), respectively. Although the positive bands for PCR products from a given genomic DNA with grade 1 or grade 2 degradation were clear, those from genomic DNA with grade 3 degradation were not because the degraded genomic DNA masked the PCR products. However, positive bands could be detected in all of the samples (Figure 2). Consequently, PCR and direct sequencing was successfully performed in all the DNA samples, even after some of the samples had been stored for 12 months, although some DNA samples extracted from the fluid-based specimens had degraded.

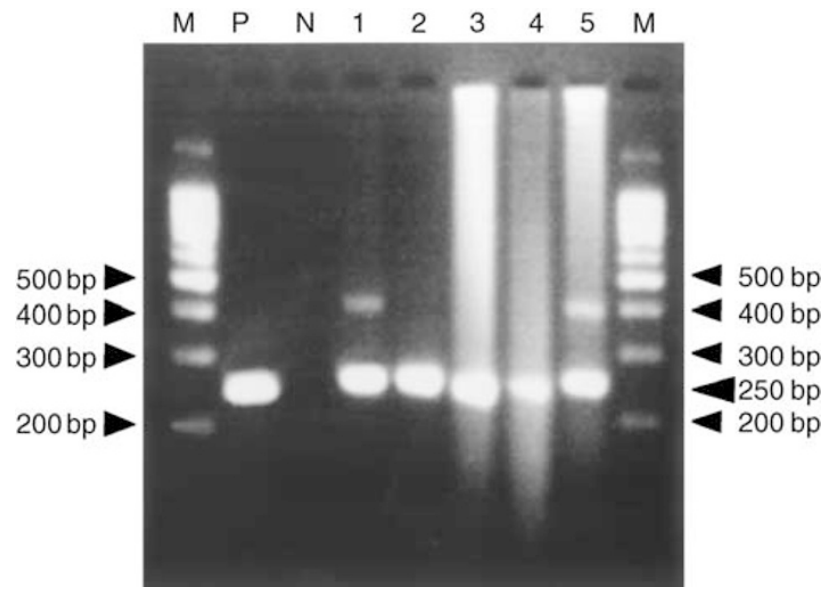

Figure 2 Detection of PCR products using electrophoresis. PCR products were electrophoresed on a 3\% agarose gel. Lane I, PCR products using genomic DNA with grade I degradation as a template; lane 2, PCR products using genomic DNA with grade 2 degradation as a template; lanes 3, 4, and 5, PCR products using genomic DNA with grade 3 degradation as a template. $M$ shows the $100-b p$ DNA ladder marker. $\mathrm{P}$ shows the positive control. $\mathrm{N}$ shows the negative control.

\section{DISCUSSION}

In this report, we performed the first large-scale study in Japan to examine the use of a new fluid-based Papanicolaou specimen collection system in 3000 Japanese women; the results were then compared to those of conventional smears. We also evaluated the use of residual fluid-based specimens after long-term storage in several molecular analyses, such as HPV screening by HC II, HPV detection by PCR, and HPV typing by sequencing.

The ThinPrep 2000 fluid-based, thin layer automated slide preparation system was designed to improve sample collection and preparation. Since fluid-based specimens can be stored at ambient temperatures for more than 1 year, this collection system is advantageous in that the Papanicolaou specimen can be reexamined several times using the residual specimen after the initial Papanicolaou test has been performed. In addition, this collection system makes it possible to perform follow-up studies without unduly inconveniencing the patient.

Several studies have reported that molecular analyses can be performed using fluid-based specimens and that these specimens enable the integrity of cellular DNA, RNA, and proteins to be retained (Lin WM et al, 2000b; Tarkowski et al, 2001). Therefore, molecular analyses can be performed using the residual specimen after a cytological diagnosis has been made, without the need to collect a second specimen from the patient. To our knowledge, however, the use of fluid-based Papanicolaou test specimens for HPV detection has not been reported in Japan.

This study of 3000 patients demonstrated that the quality of fluid-based ThinPrep slides is similar to that of conventional Papanicolaou smears, with regard to their use in screening and cervical neoplasia detection. Our results revealed a high concordance rate between the ThinPrep slide and conventional Papanicolaou smear test results. The CIN and SCC detection sensitivities and the percentage of cases with benign atypia did not differ between the two methods. However, some studies in Europe and America have reported an increased sensitivity for the detection of cervical neoplasia using the ThinPrep slide method (Awen et al, 1994; Linder and Zahniser, 1997; Roberts et al, 1997; Papillo et al, 1998). Other studies have reported that the rate of atypical squamous cells of undetermined significance decreased with the use of ThinPrep slides (Bolick and Hellman, 1998; Park 
et al, 2001). These differences are probably related to differences in cervical neoplasia screening programmes. In Japan, more than 5000 cytotechnologists are working in this field, so cytotechnologists can spend a longer time per case than in other countries. Although the two methods are similar in quality, we prefer the fluid-based Papanicolaou test because fluid-based specimens can be stored at ambient temperatures for long periods and can be used in other ways, such as in molecular analyses.

HC II was recently reported to be a useful kit for detecting HPV DNA (Clavel et al, 1998; Lin CT et al, 2000a; Castle et al, 2002). Thirteen types of high-risk HPV and five types of low-risk HPV can be detected using HC II. Ferenczy reported that the fluid-based cytologic system provides adequate material for hybrid capture tests (Ferenczy et al, 1996). Our results also showed that fluidbased specimens could be used in the HC II test. The sensitivity of HC II for detecting CIN and SCC was the same as that of the ThinPrep slides. The sensitivity of HC II for detecting HGSIL was also similar to previously reported values (73-93\%) (Clavel et al, 1998; Kuhn et al, 2000; Lin CT et al, 2000a; Yamazaki et al, 2001). HC II may be a useful test for detecting cervical neoplasia in countries without cytologic screening systems. We prefer the Papanicolaou test, however, because more information, such as the grade of the dysplastic cells, can be obtained; the sensitivities of the Papanicolaou and HC II tests were similar.

We found that HPV 16 and HPV 52 were the predominant HPV types found in CIN3 and SCC, based on the direct sequencing of PCR products; consequently, CIN cases that are positive for these HPV types should be more strictly followed up than cases positive for other HPV types. Yoshikawa et al (1999) reported that HPV types $16,18,31,33,51,52$, and 58 were predominantly detected in HGSIL. Sasagawa et al. (2001) reported that HPV types 16, 31, 33, $35,45,51,52,56$, and 58 were associated with HGSIL, while HPV types $16,18,31,51,52$, and 58 were associated with SCC; thus infection with HPV type $16,18,31,51,52$, or 58 is considered to be associated with a high-risk of CIN and SCC in Japanese women. Our results also revealed that HPV 18 was predominantly detected in adenocarcinoma, as previously reported (Lizano et al, 1997; Shyu et al, 2001). We previously reported that the incidence of multiple HPV coinfection was $38.3 \%$ in cervical dysplasia (Nakagawa et al, 2002). The significance of multiple HPV coinfection is controversial; therefore, our strategy for elucidating cells with multiple HPV coinfection to be performed in the future experiments may be useful.

The concordance rate between HC II and PCR test results has been reported to be high (Clavel et al, 1998; Peyton et al, 1998; Terry et al, 2001), but one study reported a rate of only $83 \%$ (Yamazaki et al, 2001). Our concordance rate (81.2\%) was similar to that in the report by Yamazaki et al. Our study also revealed that the concordance rate between test results in CIN1 cases $(68.1 \%)$ was lower than that in more progressive lesions (88.4\%). The cause of the lower concordance rate among CIN1 cases is probably related to a low copy number of the HPV genome and a higher PCR sensitivity for the detection of HPV. In addition, HPV types that were not included in Probe B cocktail of HC II or unknown types of HPV can be detected using the PCR method.

In conclusion, the fluid-based Papanicolaou test produces specimens of the same quality as those produced using conventional Papanicolaou smears. ThinPrep sample vials can be stored at ambient temperature for periods of more than 1 year; furthermore, the detection of HPV DNA can be performed using residual specimens after cytological or biopsy studies have been completed. Moreover, a follow-up protocol consisting of concurrent cytology and HPV-DNA detection can be performed in patients with a high risk of CIN or SCC. This collection system should enable significant advances in molecular epidemiology and is useful for identifying high-risk cases of cervical cancer.

\section{ACKNOWLEDGEMENTS}

We acknowledge the support of Grand-in-Aid for Scientific research (A) Japan Society for the promoter of Science and Research Grants for Life Science and Medicine, and the Keio University Medical Science Fund. We acknowledge help from Cytyc Corporation Japan, Digene and YUKA Medias, Co, Ltd. We also acknowledge help for cytology screening by HT and YN.

\section{REFERENCES}

Awen C, Hathway S, Eddy W, Voskuil R, Janes C (1994) Efficacy of ThinPrep preparation of cervical smears: a 1,000-case, investigatorsponsored study. Diagn Cytopathol 11: 33-36, discussion 36-37

Bolick DR, Hellman DJ (1998) Laboratory implementation and efficacy assessment of the ThinPrep cervical cancer screening system. Acta Cytol 42: $209-213$

Castle PE, Lorincz AT, Mielzynska-Lohnas I, Scott DR, Glass AG, Sherman ME, Schussler JE, Schiffman M (2002) Results of human papillomavirus DNA testing with the hybrid capture 2 assay are reproducible. J Clin Microbiol 40: 1088-1090

Clavel C, Masure M, Putaud I, Thomas K, Bory JP, Gabriel R, Quereux C, Birembaut P (1998) Hybrid capture II, a new sensitive test for human papillomavirus detection. Comparison with hybrid capture I and PCR results in cervical lesions. J Clin Pathol 51: 737-740

Crum CP, Genest DR, Krane JF, Hogan C, Sun D, Bellerose B, Kostopoulou E, Lee KR (1999) Subclassifying atypical squamous cells in Thin-Prep cervical cytology correlates with detection of high-risk human papillomavirus DNA. Am J Clin Pathol 112: 384-390

Ferenczy A, Robitaille J, Franco E, Arseneau J, Richart RM, Wright TC (1996) Conventional cervical cytologic smears vs. ThinPrep smears. A paired comparison study on cervical cytology. Acta Cytol 40: $1136-1142$

Fujii T, Tsukazaki K, Kiguchi K, Kubushiro K, Yajima M, Nozawa S (1995) The major E6/E7 transcript of HPV-16 in exfoliated cells from cervical neoplasia patients. Gynecol Oncol 58: 210-215

Josefsson AM, Magnusson PK, Ylitalo N, Sorensen P, Qwarforth-Tubbin P, Andersen PK, Melbye M, Adami HO, Gyllensten UB (2000) Viral load of human papilloma virus 16 as a determinant for development of cervical carcinoma in situ: a nested case-control study. Lancet 355: $2189-2193$

Kuhn L, Denny L, Pollack A, Lorincz A, Richart RM, Wright TC (2000) Human papillomavirus DNA testing for cervical cancer screening in lowresource settings. J Natl Cancer Inst 92: 818-825

Lin CT, Tseng CJ, Lai CH, Hsueh S, Huang HJ, Law KS (2000a) High-risk HPV DNA detection by hybrid capture II. An adjunctive test for mildly abnormal cytologic smears in women $>$ or $=50$ years of age. $J$ Reprod Med 45: $345-350$

Lin WM, Ashfaq R, Michalopulos EA, Maitra A, Gazdar AF, Muller CY (2000b) Molecular Papanicolaou tests in the twenty-first century: molecular analyses with fluid-based Papanicolaou technology. Am J Obstet Gynecol 183: $39-45$

Linder J, Zahniser D (1997) The ThinPrep Pap test. A review of clinical studies. Acta Cytol 41: 30-38

Lizano M, Berumen J, Guido MC, Casas L, Garcia-Carranca A (1997) Association between human papillomavirus type 18 variants and histopathology of cervical cancer. J Natl Cancer Inst 89: $1227-1231$

Nakagawa H, Sugano K, Fujii T, Kubushiro K, Tsukazaki K, Nozawa S (2002) Frequent detection of human papilloma viruses in cervical dysplasia by PCR single-strand DNA-conformational polymorphism analysis. Anticancer Res 22: $1655-1660$

Papillo JL, Zarka MA, St John TL (1998) Evaluation of the ThinPrep Pap test in clinical practice. A seven-month, 16,314-case experience in northern Vermont. Acta Cytol 42: 203-208 
Park IA, Lee SN, Chae SW, Park KH, Kim JW, Lee HP (2001) Comparing the accuracy of ThinPrep Pap tests and conventional Papanicolaou smears on the basis of the histologic diagnosis: a clinical study of women with cervical abnormalities. Acta Cytol 45: 525-531

Peyton CL, Schiffman M, Lorincz AT, Hunt WC, Mielzynska I, Bratti C, Eaton S, Hildesheim A, Morera LA, Rodriguez AC, Herrero R, Sherman ME, Wheeler CM (1998) Comparison of PCR- and hybrid capture-based human papillomavirus detection systems using multiple cervical specimen collection strategies (erratum appears in J Clin Microbiol 1999; 37(2):478.). J Clin Microbiol 36: 3248-3254

Roberts JM, Gurley AM, Thurloe JK, Bowditch R, Laverty CR (1997) Evaluation of the ThinPrep Pap test as an adjunct to the conventional Pap smear (see comments). Med J Aust 167: 466-469

Sasagawa T, Basha W, Yamazaki H, Inoue M (2001) High-risk and multiple human papillomavirus infections associated with cervical abnormalities in Japanese women. Cancer Epidemiol Biomarkers Prev 10: $45-52$

Shyu JS, Chen CJ, Chiu CC, Huang SC, Harn HJ (2001) Correlation of human papillomavirus 16 and 18 with cervical neoplasia in histological typing and clinical stage in Taiwan: an in situ polymerase chain reaction approach. J Surg Oncol 78: 101-109
Tarkowski TA, Rajeevan MS, Lee DR, Unger ER (2001) Improved detection of viral RNA isolated from liquid-based cytology samples. Mol Diagn 6: $125-130$

Terry G, Ho L, Londesborough P, Cuzick J, Mielzynska-Lohnas I, Lorincz A (2001) Detection of high-risk HPV types by the hybrid capture 2 test. J Med Virol 65: 155-162

Woodman CB, Collins S, Winter H, Bailey A, Ellis J, Prior P, Yates M, Rollason TP, Young LS (2001) Natural history of cervical human papillomavirus infection in young women: a longitudinal cohort study. Lancet 357: $1831-1836$

Yamazaki H, Sasagawa T, Basha W, Segawa T, Inoue M (2001) Hybrid capture-II and LCR-E7 PCR assays for HPV typing in cervical cytologic samples. Int J Cancer 94: 222-227

Yoshikawa H, Kawana T, Kitagawa K, Mizuno M, Yoshikura H, Iwamoto A (1991) Detection and typing of multiple genital human papillomaviruses by DNA amplification with consensus primers. Jpn J Cancer Res 82: $524-$ 531

Yoshikawa H, Nagata C, Noda K, Nozawa S, Yajima A, Sekiya S, Sugimori H, Hirai Y, Kanazawa K, Sugase M, Shimizu H, Kawana T (1999) Human papillomavirus infection and other risk factors for cervical intraepithelial neoplasia in Japan. Br J Cancer 80: 621-624 